\title{
Peran Eksopolisakarida Azotobacter dan Bahan Organik untuk Meningkatkan Nodulasi dan Biomassa Kedelai pada Dua Ordo Tanah
}

\author{
Role of Azotobacter's Exopolysaccharide and Organic Matter on \\ Increasing Nodulation and Biomass of Soybean Grown on Two Soil Order
}

\author{
Reginawanti Hindersah $^{1 *}$, Neni Rostini ${ }^{1}$, Arief Harsono ${ }^{2}$, dan Agustinus Marthin Kalay ${ }^{3}$ \\ ${ }^{1}$ Fakultas Pertanian, Universitas Padjadjaran \\ Jl. Raya Bandung-Sumedang Km. 21 Jatinangor 45363, Indonesia \\ ${ }^{2}$ Balai Penelitian Aneka Kacang dan Umbi Litbang Pertanian Kementrian Pertanian \\ Jl. Raya Kendalpayak km 8, PO Box 66 Malang \\ ${ }^{3}$ Fakultas Pertanian, Universitas Pattimura, Jl. Ir. M Putuhena, Kampus Poka Ambon 97223
}

Diterima 20 September 2018/Disetujui 30 April 2019

\begin{abstract}
Exopolysaccharide (EPS) produced by nitrogen-fixing bacteria Azotobacter protect nitrogenase from oxygen. In legume, EPS plays a role in the immobilization of rhizobia to the roots. The objective of this experiment was to study the effect of EPS Azotobacter and organic matter on increasing number of nodules and biomass of soybeans grown in Inceptisols and Ultisols; as well as nitrogen-fixing bacteria population in soybean rhizosphere. The experiment was set up in a completely randomized block design with five replications to test combined treatments of two doses of crude EPS and organic matter. Nodule number, shoot dry weight and nitrogen uptake, as well as Azotobacter and Rhizobium population in soybean grown in Inceptisols following crude EPS and compost application, were higher than those grown in Ultisols. The application of EPS and compost In Ultisols did not affect the number of nodule and other traits, but in Inceptisols, adding $6.25 \mathrm{~g}$ of compost and $20 \mathrm{~mL}$ of EPS to each plant increased the number of nodules and shoot weight at 42 days after planting. However, the highest $N$ uptake was demonstrated by soybean received $10 \mathrm{~mL}$ and $20 \mathrm{~mL}$ EPS along with $12.5 \mathrm{~g}$ compost.
\end{abstract}

Keywords: Azotobacter, exopolysaccharide, nodule, soybean, shoot dry weght

\section{ABSTRAK}

Eksopolisakarida (EPS) yang dihasilkan bakteri pemfiksasi nitrogen Azotobacter memproteksi nitrogenase dari oksigen. Pada tanaman legume EPS berperan dalam imobilisasi rizobia ke perakaran. Tujuan percobaan ini adalah untuk mendapatkan informasi peran aplikasi EPS Azotobacter dan bahan organik terhadap jumlah nodula dan biomassa kedelai yang ditanam di tanah ordo Ultisols dan Inceptisols; serta populasi bakteri pemfiksasi $\mathrm{N}_{2}$ di rizosfer kedelai. Percobaan dirancang dalam rancangan acak kelompok dengan lima ulangan untuk menguji dua dosis bahan organik dan suspensi EPS. Jumlah nodula dan bobot kering tajuk serta populasi Azotobacter dan Rhizobium di kedelai yang ditanam di tanah ordo Inceptisols lebih tinggi daripada di Ultisols setelah pemberikan bahan organik dan suspensi EPS. Pada Ultisols, aplikasi kompos dan EPS tidak mempengaruhi jumlah nodula dan karakter lainnya, tetapi pada Inceptisols, pemberian kompos $6.25 \mathrm{~g}$ dan EPS 20 mL per tanaman meningkatkan jumlah nodula dan tinggi tanaman pada 42 hst. Namun serapan $N$ tajuk tertinggi diperoleh dari kedelai yang mendapatkan $10 \mathrm{~mL}$ dan $20 \mathrm{~mL}$ EPS yang diberikan bersamaan dengan $12.5 \mathrm{~g}$ kompos.

Kata kunci: Azotobacter, eksopolisakarida, nodula, kedelai, bobot kering tajuk

\section{PENDAHULUAN}

Azotobacter adalah Plant Growth Promoting Rhizobacteria (PGPR) penting karena mampu menyediakan $\mathrm{N}$ tersedia untuk tanaman melalui fiksasi dinitrogen $\left(\mathrm{N}_{2}\right)$

* Penulis untuk korespondensi. e-mail: reginawanti@unpad.ac.id nonsimbiotik. Rizobakteri ini juga memproduksi fitohormon dan eksopolisakarida (EPS) serta bersifat antagonistik terhadap fitopatogen. Secara alami, EPS Azotobacter dibentuk untuk melindungi sistem nitrogenase dari oksigen (Wang et al., 2017), toleransi terhadap kekeringan, induksi pembentukan sista dan biofilm serta resistensi terhadap antimikroba (Gauri et al., 2012). Di rizosfer, EPS berperan dalam stabilitas koloid tanah (Liu et al., 2013), pembentukan 
agregat tanah yang stabil (Alami et al., 2000), dan sebagai cadangan dan penyalur air ke akar tanaman ketika air terbatas (Carminati et al., 2011).

Eksopolisakarida Azotobacter adalah polimer menyerupai alginat yang mengandung asam organik dan asam uronat (Patil et al., 2010). Inokulasi ganda Azotobacter dengan Bradyrhizobium pada tanaman kedelai berdampak positif terhadap peningkatan nodulasi (Koziel et al., 2013) maupun populasi Azotobater di tanah dan hasil kedelai (Marinkovic et al., 2018). Namun penelitian mengenai EPS pada kedelai jarang dilakukan padahal EPS Azotobacter maupun kultur sel Azotobacter pada kedelai juga menginduksi pembentukan nodula kedelai di rumah kaca (Hindersah et al., 2018).

Tanaman kacang-kacangan dapat memfiksasi 30-150 $\mathrm{kg} \mathrm{N} \mathrm{ha-1} \mathrm{(Unkovich} \mathrm{et} \mathrm{al.,} \mathrm{2008)} \mathrm{dan} \mathrm{kedelai} \mathrm{termasuk}$ legum penting di Indonesia; dengan ekstensifikasi ke tanah suboptimal seperti Inceptisols dan Ultisols (Dariah dan Heryani, 2014). Peran EPS Azotobacter dalam nodulasi akan berdampak terhadap penyerapan unsur hara nitrogen dan selanjutnya biomassa tanaman. Baik Azotobacter maupun Rhizobium bersifat heterotrof yang memerlukan bahan organik sebagai sumber karbon dan energi (Bergey dan Holt, 1994). Bahan organik pada pertanaman kedelai berfungsi bukan saja untuk meningkatkan kesuburan tanah tetapi juga menjamin proliferasi bakteri Azotobacter dan Rhizobium. Penelitian ini penting dilakukan untuk membandingkan efek EPS Azotobacter dan bahan organik terhadap jumlah nodula dan bobot tajuk kedelai yang ditanam di tanah ordo Inceptisols dan Ultisols; serta serta populasi bakteri pemfiksasi $\mathrm{N}_{2}$ nonsimbiotik Azotobacter dan bakteri pemfiksasi N simbiotik Rhizobium di rizosfer kedelai.

\section{BAHAN DAN METODE}

Percobaan dilakukan di Fakultas Pertanian Universitas Padjadjaran, Jatinangor, Kabupaten Sumedang, Jawa Barat dengan ketinggian tempat $772.5 \mathrm{~m}$ di atas permukaan laut pada Juni-Agustus 2015. Bakteri pemfiksasi nitrogen Azotobacter sp. penghasil EPS dan Bradyrhizobium diisolasi dari rizosfer kedelai kultivar Anjasmoro yang ditanam di Balai Penelitian Aneka Kacang dan Umbi Malang pada April 2015.

Tanah Inceptisols dan Ultisols dari Jatinangor bertekstur masing-masing liat berdebu dan liat dengan karakteristik kimia pada Tabel 1, diambil secara komposit dari lapisan atas tanah sampai kedalaman $20 \mathrm{~cm}$ sebelum dicampur dengan kompos kotoran sapi. Komposisi kompos adalah $\mathrm{C}$ organik $33.53 \%, \mathrm{~N}$ organik 1.8\%, rasio $\mathrm{C} / \mathrm{N} 18$, kadar air 22.34\%, pH 6.21, $\mathrm{P}_{2} \mathrm{O}_{5} 1.2 \%$ dan $\mathrm{K}_{2} \mathrm{O} 3.71 \%$; yang diberikan dua dosis yaitu setara 2.5 ton ha $\mathrm{ha}^{-1}$ dan 5 ton ha ${ }^{-1}$.

Percobaan dirancang dalam Rancangan Acak Kelompok yang menguji 5 kombinasi perlakuan dosis bahan organik dan EPS pada dua ordo tanah yaitu Inceptisols dan Ultisols. Kombinasi perlakuan bahan organik dan EPS adalah: Kontrol (tanpa bahan organik dan tanpa EPS), Kompos $6.25 \mathrm{~g}$, suspensi EPS Azotobacter $10 \mathrm{~mL}$ per polibag, Kompos 6.25 g, suspensi EPS Azotobacter $20 \mathrm{~mL}$ per polibag, Kompos 12.5 g, suspensi EPS Azotobacter 10 $\mathrm{mL}$ per polibag, Kompos $12.5 \mathrm{~g}$, suspensi EPS Azotobacter $20 \mathrm{~mL}$ per polibag.

Lima perlakuan di atas diaplikasikan pada kedua ordo tanah sehingga terdapat 10 perlakuan yang masing-masing diulang lima kali sehingga terdapat 50 polibag.

\section{Persiapan Inokulan dan suspensi eksopolisakarida}

Kultur cair Azotobacter diproduksi pada media molase $1 \%$ dengan $\mathrm{NH}_{4} \mathrm{Cl} 0.5 \%$, diperkaya sistein dan serin. Setelah media disterilisasi pada $121{ }^{\circ} \mathrm{C}$ selama 20 menit, sebanyak 5\% biakan murni Azotobater dengan kepadatan $10^{8} \mathrm{CFU}$ per gram tanah diinokulasikan. Media ditempatkan di dalam fermentor ukuran $2 \mathrm{~L}$ pada suhu kamar dengan pengadukan $115 \mathrm{rpm}$. Pada hari ketiga inokulan cair Azotobacter disentrifugasi pada kecepatan $9000 \mathrm{rpm}$ dengan suhu $4{ }^{\circ} \mathrm{C}$ selama 20 menit dan supernatan yang mengandung EPS dikoleksi sebagai suspensi eksopolisakarida.

\section{Persiapan Media Tanam dan Penanaman}

Tanah ordo Inceptisol dan Ultisols asal Kampung Ciparanje, Desa Hegarmanah, Kecamatan Jatinangor, Kabupaten Sumedang, dikeringanginkan, ditimbang seberat $5 \mathrm{~kg}$ dan dimasukan ke dalam polibag dengan diameter $18 \mathrm{~cm}$ dan tinggi $22 \mathrm{~cm}$. Tanah dicampur dengan pupuk kandang sapi sesuai dosis dan suspensi EPS Azotobacter yang masing mengandung Azotobacter sebanyak $10^{2} \mathrm{CFU}$ $\mathrm{mL}^{-1}$. Suspensi EPS dengan volume $10 \mathrm{~mL}$ atau $20 \mathrm{~mL}$ diencerkan sampai volume $100 \mathrm{~mL}$, disemprotkan merata ke tanah, dan tanah diaduk merata. Tanah ditutup terpal selama 7 hari.

Benih kedelai varietas Anjasmoro diinokulasi dengan inokulan cair Bradyrhizobium yang diproduksi pada media agar mannitol ragi pada kepadatan $10^{7} \mathrm{CFU} \mathrm{mL}^{-1}$. Inokulasi dilakukan dengan merendam 100 butir benih di dalam 110 $\mathrm{mL}$ inokulan cair selama 10 detik. Lubang tanam pada tanah di polibag dibuat dengan cara tugal sedalam $5 \mathrm{~cm}$ dan dua benih kedelai ditanam di satu lubang. Penjarangan dilakukan pada dua minggu setelah tanam dan hanya satu tanaman terbaik yang dipelihara sampai fase vegetatif akhir yaitu 42 hari setelah tanam (hst) dengan kondisi air tanah pada kapasitas lapang.

Tanaman dipupuk dengan $0.2 \mathrm{~g}$ urea, $0.25 \mathrm{~g} \mathrm{SP}-36$ dan $0.25 \mathrm{~g} \mathrm{KCl}\left(75 \mathrm{~kg}\right.$ Urea ha ${ }^{-1}, 100 \mathrm{~kg} \mathrm{SP}-36 \mathrm{ha}^{-1}$ dan $100 \mathrm{~kg}$ $\mathrm{KCl} \mathrm{ha-1}$ ). Pupuk diaplikasikan pada 4 hari setelah tanam (hst) dengan cara ditugal di dua lubang dengan kedalaman 5 cm dekat dengan perakaran tanaman. Satu lubang untuk Urea dan satu lubang lagi untuk SP-36 dan KCl. Pengendalian lalat bibit Agromyza phaseoli yang menyerang tanaman kedelai pada umur 3-5 hari menggunakan pestisida berbahan aktif Deltametrin $25 \mathrm{~g} \mathrm{~L}^{-1}$ dengan konsentrasi $2 \mathrm{~mL} \mathrm{~L}^{-1}$. 


\section{Pengukuran Parameter dan Analisis Statistik}

Pada fase vegetatif akhir, minggu ke enam, tajuk tanaman dipisahkan dari bagian akar; kemudian tajuk dikeringkan pada $60{ }^{\circ} \mathrm{C}$ sampai berat konstan selama 2 hari, Jumlah nodula efektif dihitung yang ditandai dengan ukurannya lebih dari $2 \mathrm{~mm}$, bernas dan berwarna merah jika nodula dibelah menandakan keberadaan leghemoglobin. Konsentrasi $\mathrm{N}$ tajuk ditetapkan dengan metode Kjeldahl sedangkan kadar C-organik tanah dengan metode Walkley and Black (Sulaeman dan Eviati, 2012). Serapan N dihitung dengan mengalikan persentase nitrogen dengan bobot kering tajuk tanaman kedelai. Bobot isi tanah ditetapkan menggunakan contoh tanah utuh yang diambil dengan ring sampel diamter $5 \mathrm{~cm}$ setelah ring sample dipanaskan $105^{\circ} \mathrm{C}$ selama 24 jam.

Tanah rizosfer dikoleksi dari permukaan akar setelah bongkahan tanah dihilangkan. Sampel berasal dari sampel komposit yang menggabungkan tanah rizosfer dari lima ulangan dengan perlakuan yang sama. Sampel dikompositkan karena tanah rizosfer di perakaran satu tanaman kedelai tidak mencukupi untuk analisis penghitungan bakteri dengan metode plat pengenceran berseri. Bakteri Azotobacter dan Bradyrhizobium di rizosfer masing-masing dihitung menggunakan media agar Ashby bebas nitrogen dan agar manitol ragi dengan bromthymol blue. Seluruh data kecuali populasi bakteri dianalisis dengan analisis ragam (Uji F) dan dilanjutkan dengan Uji Duncan pada taraf 5\%.

\section{HASIL DAN PEMBAHASAN}

\section{Jumlah nodula dan Pertumbuhan Tanaman}

Sebelum percobaan, C-organik Ultisols lebih rendah daripada Inceptisols, dan tekstur Ultisols lebih berat daripada Inceptisols (Tabel 1) yang dapat menghambat pertumbuhan tanaman. Kemasaman kedua ordo tanah yaitu 5.6 pada Ultisols dan 6.4 pada Inceptisols sesuai untuk tanaman kedelai (Koesrini et al., 2015).

Aplikasi EPS dan kompos pada Ultisols tidak mempengaruhi jumlah nodula, tinggi tajuk dan bobot kering tajuk; tetapi pada Inceptisol jumlah nodula dan bobot kering tajuk dengan nyata meningkat (Tabel 2). Di akhir percobaan, kemasaman $(\mathrm{pH})$ tanah Ultisol lebih rendah daripada Inceptisol. Secara umum, jumlah nodula dan bobot kering tajuk kedelai di Ultisols dengan nyata jauh lebih sedikit daripada di Inceptisols.

Secara keseluruhan jumlah nodula per tanaman adalah rendah, penghambatan pembentukan nodula pada Ultisols menyebabkan bobot kering tajuk kedelai menurun meskipun tinggi tanaman tidak berbeda nyata. Peningkatan nodulasi pada Inceptisols ini sejalan dengan efek ekstrak kultur bebas sel $A$. vinelandii yang meningkatkan nodulasi legum melalui pembentukan protein yang dapat meningkatkan nodulasi (Burns et al., 1981). Peningkatan jumlah nodula pada Inceptisols dengan kompos $12.5 \mathrm{~g}$ dan EPS $20 \mathrm{~mL}$ sejalan dengan efek positif koinokulasi $R$. leguminosarum dan $A$. chroococcum pada jumlah nodula Faba bean (Dashadi et al., 2011).

Tekstur Inceptisols adalah liat berdebu lebih mudah untuk ditembus akar dibandingkan dengan Ultisols. Selain itu tekstur ringan dapat menginduksi mobilisasi rizobia ke permukaan akar untuk membentuk benang infeksi. Rendahnya jumlah nodula kedelai di tanah Ultisol sejalan dengan penelitian Sato et al. (2003) bahwa bobot nodula kedelai di tanah berat lebih rendah daripada di tanah ringan disertai dengan menurunnya persentase nodula berukuran 2-5 mm.

Secara umum, jumlah nodula di setiap perlakuan adalah rendah. Pembentukan nodula erat kaitannya dengan nutrisi tanah terutama nitrogen dan $\mathrm{pH}$. Ultisols dan Inceptisols mengandung $0.23 \%$ dan $0.26 \%$ N-total yang termasuk dalam kategori sedang. Penambahan pupuk Urea serta kompos kotoran sapi dapat meningkatkan kadar $\mathrm{N}$ tanah dan menekan nodulasi. Nitrogen tinggi menghambat pembentukan, jumlah dan bobot nodula karena nodulasi dipercepat oleh nitrogen rendah yaitu $<50 \mathrm{mg} \mathrm{L}^{-1}$ (Xia et al., 2017). Nodula berkembang dengan baik dan aktif jika kandungan nitrogen tanah rendah, tanah tidak terlalu masam, meskipun beberapa strain rizobia toleran terhadap kemasaman rendah (Ferguson et al., 2013).

Bobot kering tajuk tanaman di Inceptisol lebih tinggi daripada Ultisols (Tabel 2). Peningkatan ini disebabkan oleh porositas Inceptisols lebih baik dan efek dari EPS. Alami et al. (2000) membuktikan bahwa EPS mempengaruhi pertumbuhan tanaman karena serapan unsur hara $\mathrm{N}$ oleh akar meningkat sebagai respons dari peningkatan porositas tanah. Aplikasi $20 \mathrm{~mL}$ suspensi EPS disertai $6.25 \mathrm{~g}$ kompos pada Inceptisols meningkatkan bobot kering tajuk sampai $14.41 \mathrm{~g}$ yang berbeda nyata dengan perlakuan kontrol tetapi tidak berbeda nyata dengan perlakuan lainnya. Aplikasi EPS dan kompos meningkatkan serapan $\mathrm{N}$ tajuk kedelai di kedua ordo tanah tetapi tidak mempengaruhi kadar $\mathrm{N}$ tajuk (Tabel 3).

Tanaman kedelai di Inceptisols lebih responsif terhadap aplikasi EPS karena sifat fisik Inceptisols lebih ringan dibandingkan Ultisols. Di akhir percobaan, bobot isi tanah Inceptisols lebih rendah daripada Ultisols (Tabel 4)

Tabel 1. Karakteristik kimia tanah Ultisols dan Inceptisols sebelum percobaan

\begin{tabular}{|c|c|c|c|c|c|c|c|c|}
\hline \multirow{2}{*}{$\begin{array}{l}\text { Ordo } \\
\text { Tanah }\end{array}$} & \multirow{2}{*}{$\mathrm{pH}$} & \multirow{2}{*}{$\begin{array}{c}\text { C organik } \\
(\%)\end{array}$} & \multirow{2}{*}{$\begin{array}{c}\mathrm{N} \text { total } \\
(\%)\end{array}$} & \multirow{2}{*}{$\mathrm{C} / \mathrm{N}$} & \multicolumn{3}{|c|}{ Fraksi tanah (\%) } & \multirow{2}{*}{ Tekstur } \\
\hline & & & & & Pasir & Liat & Debu & \\
\hline Ultisols & 5.6 & 1.69 & 0.23 & 7.3 & 4 & 44 & 52 & Liat \\
\hline Inceptisol & 6.4 & 2.06 & 0.26 & 7.9 & 8 & 40 & 52 & Liat berdebu \\
\hline
\end{tabular}


Tabel 2. Nodula dan pertumbuhan kedelai umur 42 hari setelah aplikasi suspensi EPS dan kompos pada Ultisols dan Inceptisols

\begin{tabular}{|c|c|c|c|c|}
\hline Perlakuan & $\mathrm{pH}$ & Jumlah nodula & Tinggi tajuk $(\mathrm{cm})$ & Bobot kering tajuk (g) \\
\hline \multicolumn{5}{|l|}{ Ultisols } \\
\hline Kontrol & $5.8 \pm 0.29 a$ & $6.6 \pm 1.67 \mathrm{a}$ & $42.92 \pm 3.24 \mathrm{a}$ & $8.24 \pm 1.30 \mathrm{a}$ \\
\hline EPS $10 \mathrm{~mL}$, kompos $6.25 \mathrm{~g}$ & $5.9 \pm 0.25 \mathrm{ab}$ & $6.8 \pm 2.28 \mathrm{a}$ & $39.88 \pm 2.12 \mathrm{a}$ & $7.64 \pm 1.00 \mathrm{a}$ \\
\hline EPS $20 \mathrm{~mL}$, kompos $6.25 \mathrm{~g}$ & $5.8 \pm 0.38 \mathrm{a}$ & $6.2 \pm 3.49 \mathrm{a}$ & $41.72 \pm 2.53 \mathrm{a}$ & $8.50 \pm 1.02 \mathrm{a}$ \\
\hline EPS $10 \mathrm{~mL}$, kompos $12.5 \mathrm{~g}$ & $5.8 \pm 0.62 \mathrm{a}$ & $6.0 \pm 3.32 \mathrm{a}$ & $42.54 \pm 3.74 \mathrm{a}$ & $7.40 \pm 2.42 \mathrm{a}$ \\
\hline EPS $20 \mathrm{~mL}$, kompos $12.5 \mathrm{~g}$ & $6.1 \pm 0.66 \mathrm{ab}$ & $7.8 \pm 2.87 \mathrm{a}$ & $44.34 \pm 2.86 \mathrm{a}$ & $8.57 \pm 1.00 \mathrm{a}$ \\
\hline \multicolumn{5}{|l|}{ Inceptisols } \\
\hline Kontrol & $6.3 \pm 0.08 b c$ & $15.6 \pm 5.94 b$ & $44.66 \pm 2.75 \mathrm{a}$ & $13.33 \pm 1.53 b$ \\
\hline EPS $10 \mathrm{~mL}$, kompos $6.25 \mathrm{~g}$ & $6.3 \pm 0.08 b c$ & $13.2 \pm 6.14 \mathrm{ab}$ & $44.40 \pm 6.35 \mathrm{a}$ & $14.27 \pm 1.72 b c$ \\
\hline EPS $20 \mathrm{~mL}$, kompos $6.25 \mathrm{~g}$ & $6.4 \pm 0.09 b$ & $26.8 \pm 5.45 \mathrm{~d}$ & $46.02 \pm 4.11 \mathrm{a}$ & $14.41 \pm 1.89 \mathrm{c}$ \\
\hline EPS $10 \mathrm{~mL}$, kompos $12.5 \mathrm{~g}$ & $6.4 \pm 0.24 b$ & $13.4 \pm 6.35 \mathrm{ab}$ & $43.96 \pm 2.04 \mathrm{a}$ & $14.04 \pm 2.23 b c$ \\
\hline EPS $20 \mathrm{~mL}$, kompos $12.5 \mathrm{~g}$ & $6.4 \pm 0.09 b$ & $18.2 \pm 6.98 \mathrm{c}$ & $45.04 \pm 4.16 \mathrm{a}$ & $13.88 \pm 1.32 \mathrm{bc}$ \\
\hline
\end{tabular}

Keterangan: Angka yang ditandai dengan huruf yang sama pada kolom sama tidak berbeda nyata menurut Uji Jarak Berganda Duncan pada taraf nyata 0.05

menjelaskan bahwa pertumbuhan akar di Inceptisols dapat lebih baik meskipun tidak diukur. Tekstur Inceptisols lebih mendukung pembentukan nodula dan fiksasi $\mathrm{N}_{2}$ karena sirkulasi udara dan ketersediaan air lebih baik (Al-Saedi et al., 2016) dan meningkatkan serapan N (Tabel 3).

\section{Populasi Azotobacter dan Bradyrhizobium di rizosfer}

Aplikasi EPS dan kompos pada berbagai dosis tidak mengubah populasi Azotobacter di kedua ordo tanah tetapi menurunkan populasi Bradyhizobium di Ultisols sebesar satu $\log$ (Tabel 5). Dibandingkan dengan populasi kedua bakteri sebelum percobaan yang ditetapkan dari bulk soil, populasi Azotobacter meningkat satu log sedangkan Bradyrhizobium hanya meningkat pada Inceptisols. Peningkatan populasi bakteri karena adanya eksudat yang dilepaskan akar dan menjadi sumber nutrisi (Dennis et al., 2010) dan aplikasi kompos.
Populasi Azotobacter dan Rhizobium di Inceptisols pada kontrol masing-masing sekitar $13.5 \%$ dan $14.5 \%$ lebih tinggi daripada Ultisols yang menjelaskan bahwa mikroba pemiksasi $\mathrm{N}_{2}$ indigenus mendapatkan kondisi lingkungan yang lebih baik di Inceptisols. Kadar C-organik Inceptisols pada setiap perlakuan lebih tinggi daripada Ultisols (Tabel 4). Azotobacter dan Rhizobium adalah rizobakteri yang bersifat heterotrof, menggunakan bahan organik sebagai sumber karbon dan energi (Bergey dan Holt, 1994). Tekstur Inceptisol, liat berdebu dengan bobot isi lebih rendah (Tabel 3) memberikan lebih banyak oksigen untuk kedua bakteri pemfiksasi $\mathrm{N}_{2}$ aerobik.

Penambahan EPS dan kompos sedikit menurunkan populasi kedua bakteri di Ultisols maupun Inceptisols meskipun tidak sampai satu log. Pada Inceptisols, perlakuan $10 \mathrm{~mL}$ EPS menurunkan populasi kedua bakteri pemfiksasi $\mathrm{N}$ di rizosfer. Suspensi EPS mengandung hanya sekitar $10^{2}$ CFU $\mathrm{mL}^{-1}$ Azotobacter; penurunan populasi diduga karena

Tabel 3. Persentase dan serapan nitrogen tajuk kedelai umur 42 hari setelah aplikasi suspensi EPS dan bahan organik pada Ultisols dan Inceptisols

\begin{tabular}{lllll}
\hline \multirow{2}{*}{ Perlakuan } & \multicolumn{2}{c}{ Konsentrasi N tajuk (\%) } & \multicolumn{2}{c}{ Serapan N tajuk (mg) } \\
\cline { 2 - 5 } & \multicolumn{1}{c}{ Ultisols } & Inceptisols & Ultisols & Inceptisols \\
\hline Kontrol & $3.87 \pm 0.09 \mathrm{ab}$ & $3.72 \pm 0.27 \mathrm{ab}$ & $315.66 \pm 4.27 \mathrm{a}$ & $502.86 \pm 8.31 \mathrm{a}$ \\
EPS 10 mL, kompos $6.25 \mathrm{~g}$ & $3.96 \pm 0.25 \mathrm{ab}$ & $3.89 \pm 0.31 \mathrm{ab}$ & $322.12 \pm 6.33 \mathrm{a}$ & $555.30 \pm 8.65 \mathrm{~b}$ \\
EPS $20 \mathrm{~mL}$, kompos $6.25 \mathrm{~g}$ & $4.12 \pm 0.11 \mathrm{~b}$ & $2.14 \pm 0.41 \mathrm{a}$ & $334.14 \pm 4.66 \mathrm{~b}$ & $568.76 \pm 4.98 \mathrm{c}$ \\
EPS 10 mL, kompos 12.5 g & $3.60 \pm 0.38 \mathrm{a}$ & $4.18 \pm 0.13 \mathrm{~b}$ & $315.66 \pm 4.27 \mathrm{~b}$ & $597.96 \pm 4.95 \mathrm{~d}$ \\
EPS 20 mL, kompos 12.5 g & $3.94 \pm 0.28 \mathrm{ab}$ & $4.11 \pm 0.20 \mathrm{ab}$ & $342.80 \pm 6.47 \mathrm{~b}$ & $602.94 \pm 7.66 \mathrm{~d}$ \\
\hline
\end{tabular}

Keterangan: Angka yang ditandai dengan huruf yang sama pada kolom sama tidak berbeda nyata menurut Uji Jarak Berganda Duncan pada taraf nyata 0.05 
ada interaksi negatif dengan mikroba indigenus karena hanya $10 \mathrm{~mL}$ suspensi EPS ditambahkan. Peningkatan dosis EPS menjadi $20 \mathrm{~mL}$ per polibag diduga menginduksi proliferasi kedua mikroba untuk meningkatkan atau mempertahankan populasinya di rizosfer.

Peningkatan populasi Rhizobium di kedua ordo tanah setelah apliksi EPS $20 \mathrm{~mL}$ per polibag sejalan dengan hasil penelitian Sara et al. (2014) pada tanah Inceptisols di musim hujan. Percobaan jangka panjang selama 8 tahun juga memperlihatkan bahwa inokulasi Rhizobium dan Azotobacter mendukung proliferasi rizobia di rizosfer karena tanaman tumbuh dengan baik akibat penyedian $\mathrm{N}$ (Rawat et al., 2013).

Tabel 4. Bobot isi tanah Ultisols dan Inceptisols yang ditanami kedelai sampai umur 42 hari setelah aplikasi bahan organik dan suspensi EPS

\begin{tabular}{lcccc}
\hline \multirow{2}{*}{ Perlakuan } & \multicolumn{2}{c}{ Bobot isi $\left(\mathrm{g} \mathrm{cm}^{3}\right)$} & \multicolumn{2}{c}{ C organik $(\%)$} \\
\cline { 2 - 5 } & Ultisols & Inceptisols & Ultisols & Inceptisols \\
\hline Kontrol & $0.77 \pm 0.04 \mathrm{a}$ & $0.74 \pm 0.02 \mathrm{c}$ & $1.70 \pm 0.02 \mathrm{c}$ & $2.05 \pm 0.02 \mathrm{a}$ \\
EPS 10 mL, kompos 6.25 g & $0.87 \pm 0.04 \mathrm{~b}$ & $0.67 \pm 0.06 \mathrm{~b}$ & $1.76 \pm 0.11 \mathrm{c}$ & $2.11 \pm 0.04 \mathrm{~b}$ \\
EPS 20 mL, kompos 6.25 g & $0.88 \pm 0.04 \mathrm{~b}$ & $0.61 \pm 0.02 \mathrm{a}$ & $1.73 \pm 0.01 \mathrm{c}$ & $2.14 \pm 0.01 \mathrm{~b}$ \\
EPS 10 mL, kompos 12.5 g & $0.90 \pm 0.12 \mathrm{~b}$ & $0.58 \pm 0.01 \mathrm{a}$ & $1.81 \pm 0.13 \mathrm{~b}$ & $2.33 \pm 0.06 \mathrm{c}$ \\
EPS 20 mL, kompos 12.5 g & $0.93 \pm 0.04 \mathrm{~b}$ & $0.57 \pm 0.08 \mathrm{a}$ & $2.06 \pm 0.06 \mathrm{a}$ & $2.36 \pm 0.01 \mathrm{c}$ \\
\hline
\end{tabular}

Keterangan: Angka yang ditandai dengan huruf yang sama pada kolom sama tidak berbeda nyata menurut Uji Jarak Berganda Duncan pada taraf nyata 0.05

Tabel 5. Populasi Azotobacter dan Rhizobium di rizosfer kedelai yang ditanam di tanah ordo Ultisols dan Inceptisols

\begin{tabular}{lccrr}
\hline \multirow{2}{*}{ Perlakuan } & \multicolumn{2}{c}{$\begin{array}{c}\text { Populasi Azotobacter* } \\
\left(\times 10^{5} \mathrm{CFU} \mathrm{g}^{-1}\right)\end{array}$} & \multicolumn{2}{c}{$\begin{array}{c}\text { Populasi Rhizobium } \\
\left(\times 10^{7} \mathrm{CFU} \mathrm{g}^{-1}\right)\end{array}$} \\
\cline { 2 - 5 } & \multicolumn{1}{c}{ Ultisols } & Inceptisols & Ultisols & Inceptisols \\
\hline Kontrol & $0.25 \pm 0.08$ & $0.75 \pm 0,23$ & $15.4 \pm 0.71$ & $5.7 \pm 1.20$ \\
Kompos 6.25 g, EPS 10 mL & $8.10 \pm 0.29$ & $9.30 \pm 0.68$ & $11.6 \pm 0.40$ & $13.4 \pm 0.61$ \\
Kompos 6.25 g, EPS 20 mL & $3.80 \pm 0.55$ & $6.90 \pm 0.42$ & $9.4 \pm 0.89$ & $7.6 \pm 0.75$ \\
Kompos 12.5 g, EPS 10 mL & $5.60 \pm 0.61$ & $9.80 \pm 1.15$ & $9.6 \pm 0.50$ & $15.6 \pm 1.20$ \\
Kompos 12.5 g, EPS 20 mL & $6.50 \pm 1.13$ & $7.40 \pm 0.75$ & $6.8 \pm 0.58$ & $12.2 \pm 0.26$ \\
\hline
\end{tabular}

Keterangan: *Data berasal dari dua kali pengukuran pada sampel yang sama

\section{KESIMPULAN}

Penambahan suspensi EPS dan bahan organik hanya meningkatkan pembentukan nodula kedelai di Inceptisols. Peningkatan nodula ini menyebabkan bobot kering tajuk tanaman dan serapan N Kedelai di Inceptisols pada 42 hst lebih tinggi daripada Ultisols. Namun tinggi tanaman kedelai di kedua ordo tanah tidak berbeda, baik tanaman yang mendapatkan EPS maupun tidak. Pada Inceptisols, pemberian kompos $6.25 \mathrm{~g}$ dan EPS $20 \mathrm{~mL}$ per tanaman menghasilkan tanaman dengan jumlah nodula tertinggi pada 42 hst. Namun serapan $\mathrm{N}$ tajuk tertinggi diperoleh dari kedelai yang mendapatkan $10 \mathrm{~mL}$ dan $20 \mathrm{~mL}$ EPS yang diberikan bersamaan dengan $12.5 \mathrm{~g}$ kompos. Populasi bakteri Azotobater dan Rhizobium di rizosfer kedelai di kedua ordo meningkat dibandingkan di tanah sebelum percobaan. Di akhir percobaan, populasi kedua bakteri di Inceptisols lebih tinggi daripada di Ultisols karena tekstur Inceptisol lebih ringan, bobot isi lebih rendah dan $\mathrm{C}$-organik lebih tinggi daripada Ultisols. Bobot isi dan C-organik kedua ordo tanah dengan nyata dipengaruhi oleh apliksi EPS dan kompos. Peningkatan C-organik secara langsung dapat mendukung prolifersi sel Azotobacter yang berperan pula dalam fiksasi nitrogen; sedangkan penurunan bobot isi memfasilitasi peningkatan serapan $\mathrm{N}$ oleh tajuk kedelai.

\section{UCAPAN TERIMA KASIH}

Penelitian ini adalah bagian dari skema Penelitian Strategis Nasional 2015 Dirjen Pendidikan Tinggi Kementerian Pendidikan RI. Kami berterimakasih kepada Yosaera Thoriq Ramadhan yang membantu pelaksanaan penelitian. 


\section{DAFTAR PUSTAKA}

Alami, Y., W. Achouak, C. Marol, T. Heulin. 2000. Rhizosphere soil aggregation and plant growth promotion of sunflowers by an exopolysaccharideproducing Rhizobium sp. strain isolated from sunflower roots. Appl. Environ. Microbiol. 66:33933398.

Al-Saedi, S.A., I.B. Razaq, N. A. Ali. 2016. Effect of soil textural classes on the biological nitrogen fixation by Bradyrhizobium measured by ${ }^{15} \mathrm{~N}$ dilution analysis. Baghdad Sci. J. 13:734-743.

Bergey. D.H., J.G. Holt. 1994. Bergey's Manual of Determinative Bacteriology. Williams \& Wilkin, Baltimore, USA.

Burns, T.A., P.E. Bishop, D.W. Israel. 1981. Enhanced nodulation of leguminous plant roots by mixed cultures of Azotobacter vinelandii and rhizobium. Plant Soil 62:399-412.

Carminati, A., C.L. Schneider, A.B. Moradi, M. Zarebanadkouki, D. Vetterlein, H.J. Vogel, A. Hildebrandt, U. Weller, L. Schüler, S.E. Oswald. 2011. How the rhizosphere may favor water availability to roots. Vadose Zone J. 10:988-998.

Dariah, A., N. Heryani. 2014. Pemberdayaan lahan kering suboptimal untuk mendukung kebijakan diversifikasi dan ketahanan pangan. J. Sumberdaya Lahan Edisi Khusus:1-16.

Dashadi, M., H. Khosravi, A. Moezzi, H. Nadian, M. Heidari, R. Radjabi. 2011. Co-inoculation of Rhizobium and Azotobacter on growth indices of faba bean under water stress in the green house condition. Adv. Studies Biol. 3:373-385.

Dennis, P.G., A.J. Miller, P.R. Hirsch. 2010. Are root exudates more important than other sources of rhizodeposits in structuring rhizosphere bacterial communities?. FEMS Microbiol. Ecol. 72:313-327.

Ferguson, B.J., M.H Lin, P. M. Gresshoff. 2013. Regulation of legume nodulation by acidic growth conditions. Plant Signal Behav. 8:e23426.

Gauri, S.S., S.M. Mandal, B.R. Pati. 2012. Impact of Azotobacter exopolysaccharides on sustainable agriculture. Appl. Microbiol. Biotechnol. 95:331338 .
Hindersah, R., N. Rostini, D.S. Sara, A. Harsono. 2018. Increasing soybean nodulation and growth following inoculation of exopolysachharide producing Azotobacter in pot culture. Asian J. Microbiol. Biotech. Env. Sci. 20:S52-S58.

Juandi, M., Y. Hasanah, S. Silitonga. 2013. Produksi kedelai (Glycine $\max$ L. Merill) dengan pemberian berbagai sumber unsur hara $\mathrm{N}$ dan perbedaan kondisi air tanah. Agroekotek. 1:535-541.

Koesrini, K. Anwar dan E. Berlian. 2015. Penggunaan kapur dan varietas adaptif untuk meningkatkan hasil kedelai di lahan sulfat masam aktual. Berita Biologi. 14:155-161.

Kozieł, M., B. Gębala, S. Martyniuk. 2013. Response of soybean to seed inoculation with Bradyrhizobium japonicum and with mixed inoculants of B. japonicum and Azotobacter chroococcum. Pol. J. Microbiol. 62:457-460.

Liu Liu, X., K. Eusterhues, J. Thieme, V. Ciobota, C. Höschen, C.W. Mueller, K. Küsel, I. KögelKnabner, P. Rösch, J. Popp, K.U. Totsche. 2013. STXM and NanoSIMS investigations on EPS Fractions before and after adsorption to Goethite. Environ. Sci. Technol. 47:3158-3166.

Marinković, J., D. Bjelić, B. Tintor, J. Miladinović. V. Dukić, V. Đorđević. 2018. Effects of soybean co-inoculation with plant growth promoting rhizobacteria in field trial. Rom. Biotech. Lett. 23:13401-13408.

Patil, S.V., R.B. Salunkhe, C.D. Patil, D.M. Patil, B.K. Salunke. 2010. Bioflocculant exopolysaccharide production by Azotobacter indicus using flower extract of Madhuca latifolia L. Appl. Biochem. Biotechnol. 162:1095-108.

Rawat, A.K., D.L.N. Rao, R.K. Sahu, 2013. Effect of soybean inoculation with Bradyrhizobium and wheat inoculation with Azotobacter on their productivity and $\mathrm{N}$ turnover in a Vertisol. http://agris.fao.org/ agris-search/search.do?recordID= US201500160199 [14 November 2016].

Sara, D.S., R. Hindersah, M.R. Setiawati. 2014. Peningkatan populasi Bradyrhizobium di rizosfer dan pertumbuhan vegetatif kedelai melalui aplikasi eksopolisakarida Azotobacter. hal. 319-323. Dalam D. Kurnia, D. Chaerani, L. Safriani (Eds.). Prosiding Seminar Nasional MIPA. Jatinangor 18 Oktober 2014. 
Sato, T., Y. Kaneta, N. Furuta, H. Kobayashi, H. Shindo, T. Ota, A. Sato. 2003. Effect of soil physical properties on soybean nodulation and $\mathrm{N}_{2}$ fixation at the early growth stage in heavy soil field in Hachirougata Polder, Japan. J. Soil Sc. Pl. Nutr. 49:695-702.

Sulaeman, Eviati. 2012. Petunjuk Teknis Analisis Kimia Tanah, Tanaman, Air dan Pupuk. Badan Penelitian dan Pengembangan Pertanian, Kementerian Pertanian, Jakarta.

Unkovich, M., D. Herridge, M. Peoples, G. Cadisch, R. Boddey, K. Giller, B. Alves, P. Chalk. 2008.
Measuring plant-associated nitrogen fixation in agricultural systems. ACIAR Monograph No. 136, $258 \mathrm{pp}$.

Wang, D., A. Xu, C. Elmerich, L.Z. Ma. 2017. Biofilm formation enables free-living nitrogen-fixing rhizobacteria to fix nitrogen under aerobic conditions. The ISME Journal 11:1602-1613.

Xia, X., C. Ma, S. Dong,Y. Xu, Z. Gong. 2017. Effects of nitrogen concentrations on nodulation and nitrogenase activity in dual root systems of soybean plants. Soil Sci. Plant Nutr. 63:470-482. 